\title{
Measurement of total serum IgE antibody in patients with atopic dermatitis
}

\author{
Amir A. Al-Hafedh*, Haitham B. Fathi**
}

* Department of Medicine, College of Medicine, ** Department of Medicine, Nineveh College of Medicine, University of Mosul.

(Ann. Coll. Med. Mosul 2011; 37 (1 \& 2): 66-70).

Received: $9^{\text {th }}$ Nov 2010; Accepted: $5^{\text {th }}$ Jun 2011.

\begin{abstract}
Objectives: To estimate the difference in total serum IgE level between patients with atopic dermatitis (AD) and healthy control subjects and to correlate age and gender of patients, and severity of AD with total serum IgE level.

Patients and methods: This is a case-series study on 52 patients with $A D$, recruited from dermatology clinic at Al-Jumhoori teaching hospital in Mosul, during the first half of 2010. Twenty five healthy non-atopic subjects were recruited from same clinic as a control group.

Results: The total serum IgE level in patients with AD was 286.0 (SD 83.1) IU/ml; corresponding value in control group was 47.8 (SD 38.1) IU/ml. Thus, total serum IgE level was significantly higher in patients with $A D$ than in control group $(p=0.007)$. The highest concentration of total serum IgE level was found among females $(p=0.04)$, age group 11-15 year $(p=0.09)$, and severe cases of $A D$ $(p=0.007)$.
\end{abstract}

Conclusion: Majority of patients with $A D$ have a raised total serum IgE level, which in turn correlates well with female gender, age group 11-15 year, and severity of disease.

الخلاصة

الأهداف: لقياس الفرق في قدر الكلوبين المناعي الكلي نوع (إي) بين المرضى المصابين بالتهاب الجلد الاستشرائي

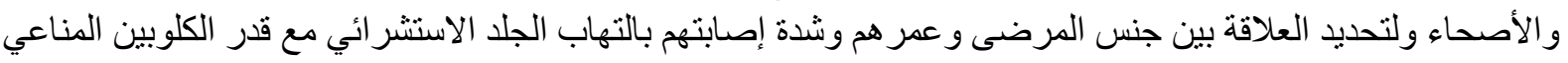
الكلي نوع (إي). العينة وطريقة البحث: أجري البحث على سلسلة مكونة من ب ه مريضا بداء التهاب الجلد الاستشر ائي نم اختبار هم من بين

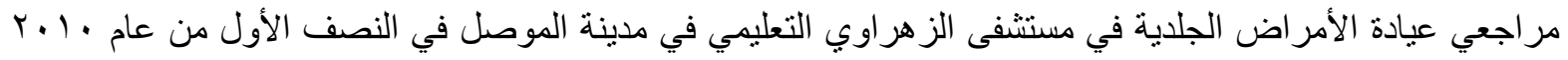

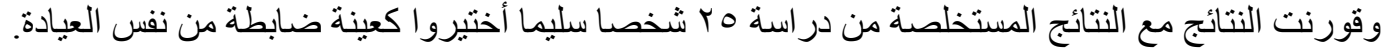

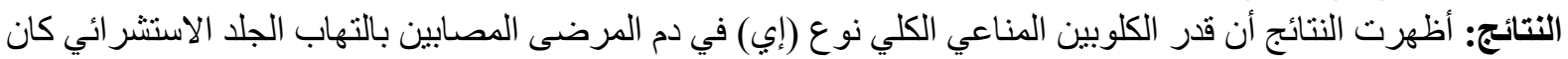

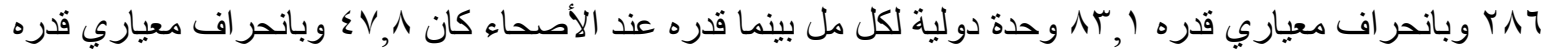

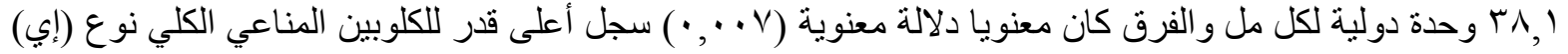

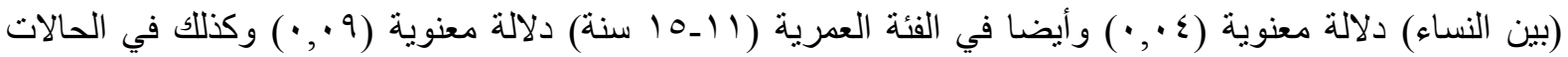

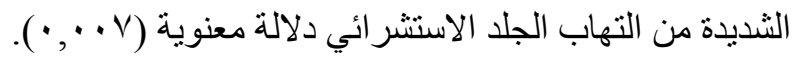

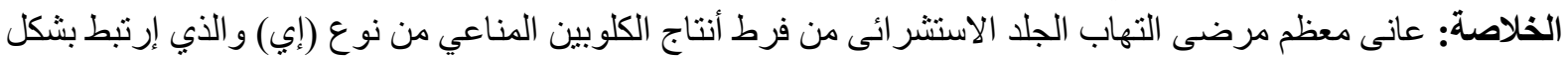

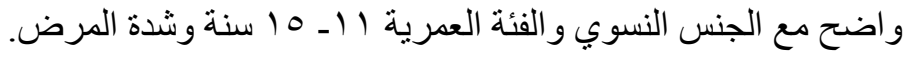


A topic dermatitis (AD) is a chronic, remitting relapsing immune-mediated inflammatory skin condition. The main immunological abnormality is excessive formation of total $\lg \mathrm{E}^{(1)}$. Despite the extensive studies, picture of $A D$ is still fragmented and controversies remain unsolved. Some of these controversies are the relationship of gender, age, and severity of $A D$ with total serum $\lg E$ level. Gender of patient was the interest of many investigators but their conclusions were controversial $^{(2,3)}$. From a clinical perspective, supported by epidemiological investigations, there is a decline with age in both incidence and severity of atopic diseases. This is in association with general humoral alteration manifested by decline in IgE level with age ${ }^{(4)}$. The severity of $A D$ also has some positive correlation with serum IgE level, but this is not a consistent observation ${ }^{(5)}$. Hence, the current study was performed to elucidate the correlation between age, gender and the severity of $A D$ with serum total IgE level. To the best of our knowledge, this is the first study of its kind from our locality.

\section{Patients and methods}

The study was conducted as a case-series study. Fifty two consecutive patients with atopic dermatitis were recruited from dermatology clinic at Al-Jumhoori teaching hospital in Mosul, from January to June 2010. The inclusion criteria adopted were clinical manifestations of $A D$ when enrolled in the study and patients agreement. The following patients were excluded: patients with other allergic diseases, disease inducing higher serum IgE level, or patients using topical/ or systemic immune-modulator treatments.

The diagnosis of $A D$ was based on fulfilling Hanifin and Rajka's major and minor criteria ${ }^{(6)}$. The severity of atopic dermatitis was based on the use of Six Areas, Six Signs Atopic Dermatitis (SASSAD) severity score ${ }^{(7)}$. The clinical severity was graded as mild (localized chronic forms with $<10 \%$ of the body surface area involved), moderate (disseminated lesions over trunk and extremities), and severe forms (e.g., more generalized eczema).

Twenty five relatives of other patients, who attended the clinic and who have no history of atopic diseases were asked to participate in this study, as a control group. They were matching patients in age and gender.

Five $\mathrm{ml}$ of blood was taken from both patients and control group for estimating total serum $\lg \mathrm{E}$ antibody. The blood was left to clot at room temperature and then centrifuged at $3000 \mathrm{rpm}$. The total serum IgE antibody was measured by Enzyme Linked immuneFluorescent Assay technique (ELFA) performed by mini VIDAS. The kit was provided by bio Mérieux, France. The kit provided a quantative in vitro assay for human total IgE antibody.

\section{Statistical methods}

Different descriptive statistical methods were used to summarize the data in this study. Independent two sample student T-test was used to compare the mean differences in total serum IgE level between patients and control group, also between male and female patients with $A D$. One way ANOVA test with post hoc dunnette's test were used to assess mean difference in total serum IgE level among different categories of severity of AD. Person linear regression test was used to evaluate age-associated changes in total serum IgE level. A p-value of $<0.05$ was considered significant. Statistical processing were conducted by the use of statistical package SPSS ver. 10 (SPSS inc, Chicago, III).

\section{Results}

The age of patients with AD ranged from 4 to 25 year with mean and standard deviation (SD) of 14.5 and 6.1 year respectively. There were 20 (38.5\%) females and 32 (61.5\%) males. The age of control group ranged 6 to 24 year with mean (SD) of 13.1 (5.5) year, and included $10(40 \%)$ females and 15 (60\%) males.

The mean total serum IgE level in patients with $A D$ was $286.0 \mathrm{IU} / \mathrm{ml}$ (SD 83.1) and the corresponding value $47.8 \mathrm{IU} / \mathrm{ml}$ (SD 38.1) for control group table (1). The difference was statistically highly significant $P=0.007$ (fig 1).

The mean total serum IgE level among females $356.2 \mathrm{IU} / \mathrm{ml}$ (SD 301.4) was higher than that in males $217.4 \mathrm{IU} / \mathrm{ml}$ (SD 266.9) and 
the difference was statistically significant $\mathrm{P}=$ 0.04 (fig 2).

The scattered plot (fig 3) showed poor linear relation of age of patient with total serum $\lg E$ level $(r=0.1)$. After breaking down age into 5 years age groups, highest mean total serum lgE level $427.7 \mathrm{IU} / \mathrm{ml}$ (SD 412.3) was found among those (11-15) year age group, and the lowest $81.7 \mathrm{lU} / \mathrm{ml}$ (SD 44.4) was among those of (21-25) year age group (fig 4).

A statistically significant rise in the mean total serum IgE level was found with increasing severity of AD. Figure (5) showed two and half time rise in mean serum lgE level in severe cases of $A D \quad 432.3 \quad \mathrm{IU} / \mathrm{ml}$ (SD 326.2) in comparison to mild cases $173.3 \mathrm{IU} / \mathrm{ml}$ (SD 219.8) and the difference was statistically significant $(p=0.007)$.

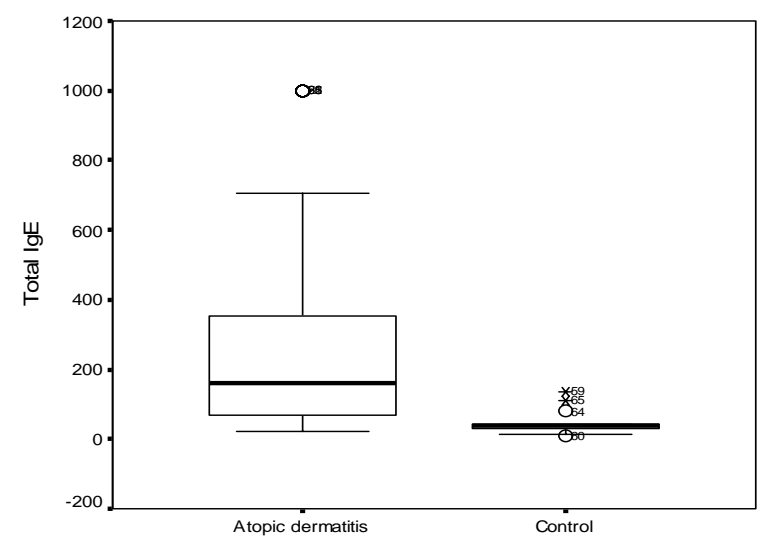

Figure (1): The difference in total serum IgE level $(\mathrm{IU} / \mathrm{ml})$ in between patients with atopic dermatitis and control group.

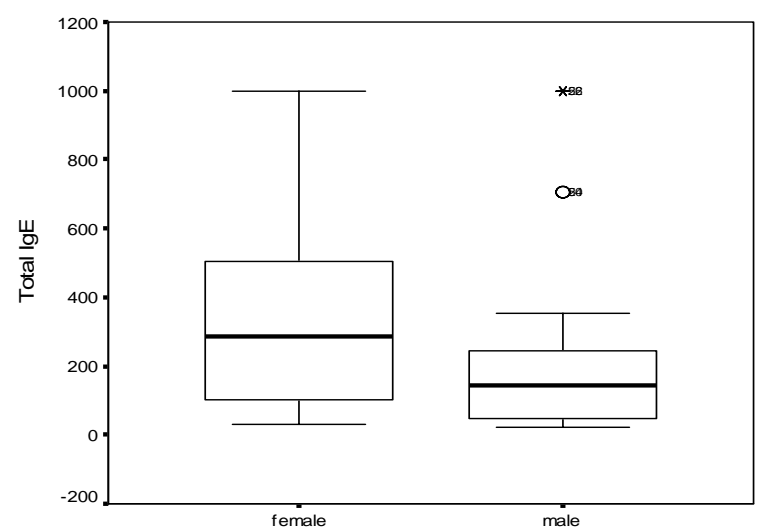

Figure (2): The difference in serum IgE level $(\mathrm{IU} / \mathrm{ml})$ between male and female patients with atopic dermatitis.

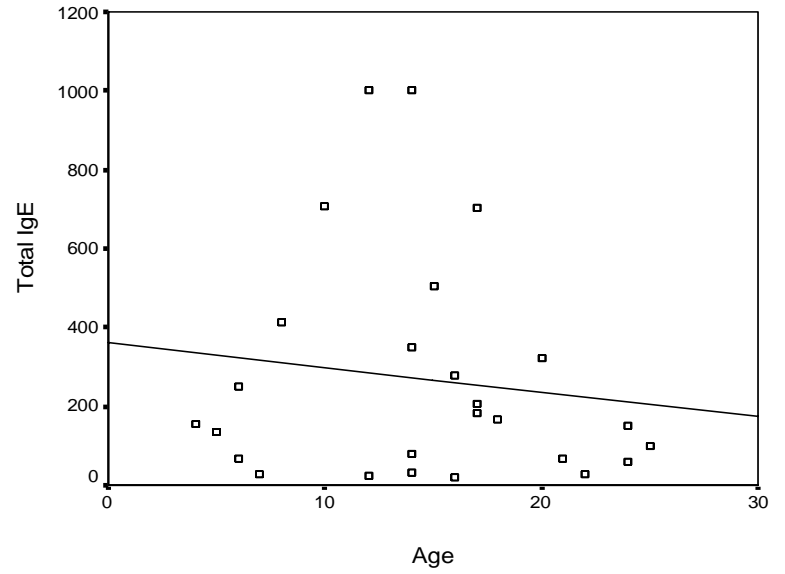

Figure (3): The relationship between total serum IgE level $(\mathrm{IU} / \mathrm{ml})$ and age of patients with atopic dermatitis.

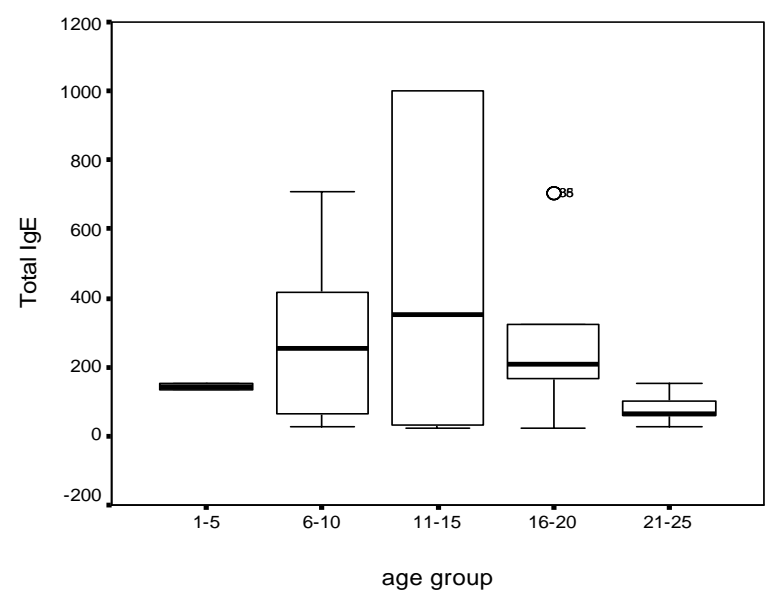

Figure (4): The relationship between total serum IgE level $(\mathrm{IU} / \mathrm{ml})$ and age group of patients with atopic dermatitis.

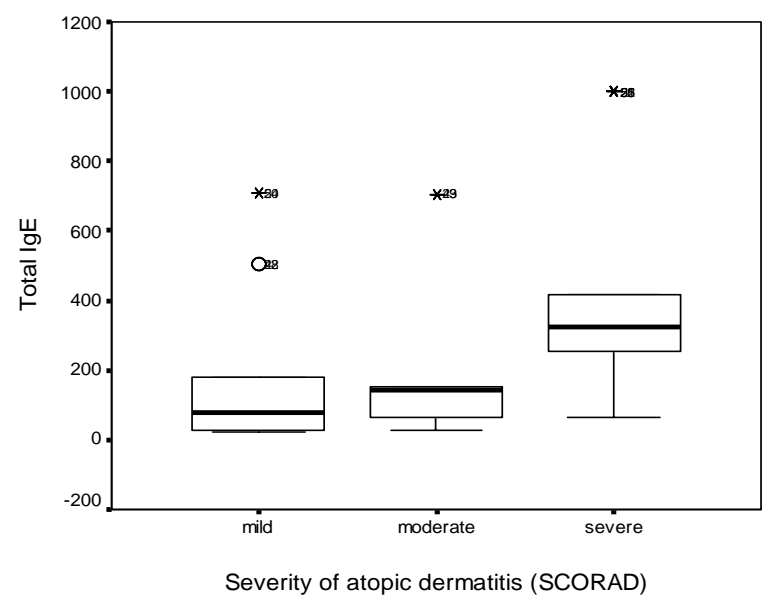

Figure (5): The level of total serum IgE (IU/ml) in patients with atopic dermatitis showing variation in severity. 
Table (1): Correlation of total serum IgE $(\mathrm{IU} / \mathrm{ml})$ with different demographic and clinical variables in patients with atopic dermatitis.

\begin{tabular}{|c|c|c|c|}
\hline Parameters & $\begin{array}{l}\text { Mean } \\
\text { (SD) }\end{array}$ & $\begin{array}{c}95 \% \\
\text { confidence } \\
\text { interval }\end{array}$ & $\begin{array}{c}\text { P- } \\
\text { value }\end{array}$ \\
\hline \multicolumn{4}{|l|}{ Gender } \\
\hline Male & $\begin{array}{c}217.4 \\
(266.9)\end{array}$ & $121.2-313.6$ & \multirow[t]{2}{*}{0.04} \\
\hline Female & $\begin{array}{c}356.2 \\
(301.4)\end{array}$ & 215.1-497.3 & \\
\hline \multicolumn{4}{|l|}{ Age group } \\
\hline $1-5$ years & $\begin{array}{l}144.9 \\
(10.4)\end{array}$ & $128.3-161.5$ & \multirow{5}{*}{0.09} \\
\hline $6-10$ years & $\begin{array}{c}293.5 \\
(262.3)\end{array}$ & $105.9-481.9$ & \\
\hline $11-15$ years & $\begin{array}{c}427.7 \\
(412.3)\end{array}$ & $189.7-665.8^{*}$ & \\
\hline $16-20$ years & $\begin{array}{c}268.6 \\
(206.2)\end{array}$ & $149.6-387.7$ & \\
\hline $21-25$ years & $\begin{array}{c}81.7 \\
(44.4)\end{array}$ & 49.9-113.5 & \\
\hline \multirow{2}{*}{$\begin{array}{l}\text { Severity of } \\
\text { atopic dermatitis } \\
\text { Mild }\end{array}$} & & & \multirow{4}{*}{0.007} \\
\hline & $\begin{array}{c}173.3 \\
(219.8)\end{array}$ & $75.8-270.7$ & \\
\hline Moderate & $\begin{array}{c}207.2 \\
(237.5)\end{array}$ & 56.3-358.1 & \\
\hline Severe & $\begin{array}{c}432.3 \\
(326.2)\end{array}$ & $\begin{array}{c}270.1- \\
594.6^{*} \mathrm{~s}^{*}\end{array}$ & \\
\hline
\end{tabular}

*Significant difference at p-value 0.05 (Dunnett's post hoc test).

\section{Discussion}

The evidence for the central role of $\operatorname{IgE}$ in etiopathogenesis of $A D$ was proved by several studies $^{(1-5)}$ including the current one. The results showed that mean total serum IgE level was six times higher among $A D$ patients in comparison to control non-atopic subjects. According to manufacturer's reference figure, $100 \mathrm{IU} / \mathrm{ml}$ is considered as a cutoff value. In this study, total serum IgE level exceeded 100 $\mathrm{IU} / \mathrm{ml}$ in $60 \%$ of patients. Raised IgE level was consistent with the findings of some studies and was slightly lower than that reported by others. Reported figures in the literature varied from $70 \%{ }^{(8)}$ to $88 \%{ }^{(9)}$ of atopic patients. These differences may be explained by the different chosen cutoff value, methods of estimating $\mathrm{lgE}$, age of participants, and severity of disease. In the above mentioned studies $^{(8,9)}$, they used $75 \mathrm{IU} / \mathrm{ml}$ as a cutoff value, patients were younger and the proportion of severe cases was larger. Our findings revealed that normal serum IgE level do not rule out the presence of $A D$ and that serum IgE may not be the only stimulus for signs and symptoms of $A D$, but definitely play an important role in their exacerbation.

Marked controversy was noted in the literature regarding the relation between gender and total serum IgE level. While Ahmed and Nasreen concluded absence of an association $^{(8)}$, Johanson et al, concluded a statistically significant association ${ }^{(10)}$. Moreover, controversy can be noticed in the direction of association; while Siroux et al concluded male preponderance ${ }^{(3)}$ Johanson et al and the current study showed a female preponderance $^{(10)}$. The dilemma of gender-IgE association requires a large population-based study.

The study revealed a gradual rise in total serum IgE level starting from the first year of age to reach its peak at age 11-15 years then, starts to decline. This pattern explains the failure of demonstrating linear relationship between age and IgE. This pattern is almost similar to the age-pattern reported by other investigators $^{(11)}$. The age at IgE decline lags behind that at clinical improvement ${ }^{(12)}$. In another word, many of the patients with $A D$ showed clinical improvement (limited lesions, less severity, infrequent relapses, and long remission) at age 5-10 year, while serum IgE needs further five years to match the clinical improvement. This time gap, is probably due to tolerance and to the fact that cascade of immunological events becomes less easily provoked by exogenous and endogenous triggering factors.

The two and half folds rise in $\operatorname{lgE}$ among patients with severe $A D$ in comparison to mild cases and the $p$-value of 0.007 support the hypothesis of association of severity of $A D$ and total serum IgE level. Corresponding to the influence of severity of $A D$ on serum IgE data in the literature are contradictory either showing no influence of severity ${ }^{(5)}$ or high level of correlation $^{(13)}$. The negative association probably is attributed to: first, small sample 
size that fails to illustrate statistical significance of difference; second, sampling error which does not cover the full spectrum of severity of the disease; and third, absence of objective measure of severity of $A D$ as the available criteria are subjective with low inter-observer agreement. Probably, future studies showing the changes in total IgE after successful treatment will provide new insight to this association.

In conclusion, high level of total serum IgE was found in patients with $A D$, especially among females, in 11-15 year age group, and in severe cases of AD. Further studies to assess the total serum IgE level in follow up of patients with atopic dermatitis is highly recommended.

\section{References}

1. Frue M. Atopic dermatitis: immunological abnormalities and its background. J Dermatol Scien 1994;7:159-68.

2. Yang KD, Liu CA, Chang JC. Polymorphism of the immune-braking gene CTLA-4 (+49) involved in gender discrepancy of serum total IgE levels and allergic diseases. Clin Exp Allerg 2004;34:32-37.

3. Siroux V, Curt V, Maccario M, Kauffmann $F$. Role of gender and hormone-related events on $\lg \mathrm{E}$, atopy, and eosinophils in the Epidemiological Study on the Genetics and Environment of Asthma, bronchial hyperresponsiveness and atopy. J Aller Clin Immunol 2004;114:491-8.

4. LeMaoult J, Szabo P, Weksler ME: Effect of age on humoral immunity, selection of the B-cell repertoire and B-cell development. Immunol Rev 1997;160:115126.
5. Laske N, Niggermann B. Does the severity of atopic dermatitis correlate with serum IgE levels? Pediatric Allergy Immunol. 2004;15:86-8.

6. Hanifin JM, Rajka G. Diagnostic features of atopic dermatitis. Acta dermatol Venereol (Stockh) 1980;92:44-9.

7. Berth-Jones J. Six area, six sign atopic dermatitis (SASSAD) severity score: a simple system for monitoring disease activity in atopic dermatitis. $\mathrm{Br} \mathrm{J}$ Dermatol 1996;135(Suppl.):25-30.

8. Ahmed I, Nasreen S. Frequency of raised IgE level in childhood atopic dermatitis. J Pak Med Assoc 2007;57:431-9.

9. Somani VK. A study of allergen-specific antibodies in Indian patients of atopic dermatitis. Indian J Dermatol Venereol Leprol 2008;74:100-104.

10. Johanson CC, Peterson EL, Ownby DR. Gender Differences in Total and Allergenspecific Immunoglobulin E (IgE) Concentrations in a Population-based Cohort from Birth to Age Four Years. J Am Epidemol 1998;147:1145-52.

11. Kang SB, Lee SB, Kim JW, Kim JK, Kim CW. Total serum IgE level in each age group of patients with atopic dermatitis. Korean J Dermatol 1988;26:507-12.

12. Linno O. Ten year prognosis for generalized infantile eczema. Arch Paed 1992;81:1013-9.

13. Dhar S, Malakar R, Chattopadhyay S, Banerjee R. Correlation of the severity of atopic dermatitis with absolute eosinophil counts in peripheral blood and serum IgE levels. Int J Dermatol 2005;71: 246-9. 